\title{
Rutin Protects from Destruction by Interrupting the Pathways Playing a Role in the Possible Damage Mechanism of Sodium Valproate in the Liver and Kidney Tissues of Rats
}

Fatih Mehmet Kandemir ( $\nabla$ fmehmet.kandemir@atauni.edu.tr )

Ataturk University: Ataturk Universitesi

Mustafa lleriturk

Ataturk University: Ataturk Universitesi

Cihan Gur

Ataturk University: Ataturk Universitesi

\section{Research Article}

Keywords: Kidney, liver, oxidative stress, rutin, sodium valproate, toxicity.

Posted Date: December 30th, 2021

Dol: https://doi.org/10.21203/rs.3.rs-1184419/v1

License: (9) (1) This work is licensed under a Creative Commons Attribution 4.0 International License. Read Full License 


\section{Abstract}

Background: The present study investigated the effects of rutin (RUT), which has various biological and pharmacological properties, on liver and kidney damage caused by histone deacetylase inhibitor valproic acid $(V L P)$, which is used in the treatment of many psychiatric disorders.

Methods and Results: In the study, 50 or 100 mg/kg RUT treatment was administered 30 minutes after 500 mg/kg VLP was given to rats for 14 days. Then, some pathways that may be involved in the damage mechanism of VLP in liver and kidney tissues were investigated using biochemical, RT-PCR and Western blotting techniques. The results show that the levels of MDA induced by VLP in liver and kidney tissues decreased after RUT treatment, and the levels of SOD, CAT, GPx and GSH suppressed by VLP increased after RUT administration. It was observed that ER stress induced by oxidative stress was alleviated by suppressing the expressions of ATF-6, PERK, IRE1 and GRP78 after RUT treatment. It was observed that the expressions of NF-kB, TNF-a, IL-6, JAK2 and STAT3 in the inflammatory pathway increased after VLP administration, while RUT treatment decreased the levels of these markers. It is also among the data obtained that the levels of markers that play a role in the regulation of apoptosis (Bax, Bcl-2, kaspaz-3, pERK, pJNK) or autophagy (Beclin-1, LC3A, LC3B) approach the control group after RUT treatment.

Conclusions: Taken together, it was determined that RUT treatment protected against liver and kidney damage by attenuating VLP-induced oxidative stress, ER stress, inflammation, apoptosis and autophagy.

\section{Introduction}

Valproic acid (VLP) and its salts are non-specific histone deacetylase inhibitors [1]. VLP has been used for more than 30 years in the treatment of epilepsy, which is one of the chronic neurological disorders that 70 million people suffer from in the world [1, 2]. It is known that the mechanism of action of VLP is inhibition of $Y$-aminobutyric acid (GABA) metabolism and interruption of GABA reuptake to nerve endings [3]. For this reason, VLP is used in the treatment of many psychiatric disorders such as migraine, bipolar disorder and schizophrenia as well as epilepsy [3-5]. Although VLP is generally a safe drug, it causes serious side effects in treatment with high concentrations. For this reason, its reliability has recently been questioned by the clinicians who initially supported it [4].

Side effects of VLP include dyspepsia, obesity, hematological toxicity, teratogenicity, hepatotoxicity, nephrotoxicity, reprotoxicity, hyperammoniemic encephalopathy, bone marrow suppression and hemorrhagic pancreatitis $[3,6]$. VLP is metabolized in the liver via cytochrome P450, fatty acid and $\beta$-oxidation. The VLP is then conjugated to highly toxic active and inactive metabolites. Examples of these are 2,4-diene-VLP, which can form glutathione conjugate by altering glutathione homeostasis, and hypoglycin, which is strongly associated with hepatotoxicity and inhibits $\beta$-oxidation [3]. Although the information about the toxicity mechanism of VLP is not clear yet, there are several mechanisms. The best known of these is the induction of oxidative stress and inflammation [3,7-9]. Therefore, substances with antioxidant and anti-inflammatory properties are intensively investigated as therapeutic options against VLP toxicity.

Flavonoids provide an important protection against oxidative stress by both scavenging reactive oxygen species (ROS) and reactive nitrogen species and increasing antioxidant enzyme activities [10]. In addition, many studies have reported that they have anti-inflammatory and anti-apoptotic properties [11-13]. It is known that rutin (RUT), a flavone derivative consisting of the flavonol quercetin and the disaccharide rutinose, [10] has similar properties 
[14-17]. In the evaluations made considering their structural features, it has been reported that the routineose molecule and four hydroxyl groups in its structure play an important role in its biological activities. In addition, it is among the information in the literature that the presence of rutinose makes it a more effective molecule by increasing the number of active sites [18].

In the present study, the effects of RUT on possible toxicity mechanisms (oxidative stress, inflammation, endoplasmic reticulum stress, apoptosis, autophagy, JAK2/STAT3 pathway and p-ERK/p-JNK pathway) caused by VLP in liver and kidney were investigated.

\section{Material And Methods}

\section{Supply and care of animals and ethical committee decision}

In the experiment, 35 male Sprague Dawley rats, aged 10-12 weeks and weighing 220-250 g were used. Animals were purchased from Atatürk University Medical Experimental Application and Research Center and all applications to animals were carried out in this center. Tap water and standard laboratory feeds were used for feeding the animals. Eating and drinking were provided ad libitum. Also, ethical approval was obtained from Atatürk University Animal Experiments Local Ethics Committee for the study (Approval No: 2021-2-32).

\section{Experiment Protocol}

In the experiment, 5 different groups with 7 animals each were formed. The dose of Rutin was determined by reference to previous studies [15, 19]. The dose of VLP was given considering the study of Zhou et al.[1].

Group 1 (Control): The rats were given orally saline solution every day for 14 days.

Group 2 (Rutin): Rats were given RUT orally at a dose of $100 \mathrm{mg} / \mathrm{kg}$ for 14 days.

Group 3 (Sodium Valproate): Sodium valproate was given orally to rats at a dose of $500 \mathrm{mg} / \mathrm{kg}$ for 14 days to induce hepatotoxicity and nephrotoxicity.

Group 4 (Sodium Valproate + Rutin $50 \mathrm{mg} / \mathrm{kg}$ ): RUT was given orally at a dose of $50 \mathrm{mg} / \mathrm{kg} / \mathrm{body}$ weight 30 minutes after sodium valproate was administered orally to rats at a dose of $500 \mathrm{mg} / \mathrm{kg}$ for 14 days.

Group 5 (Sodium Valproate + Rutin $50 \mathrm{mg} / \mathrm{kg}$ ): RUT was given orally at a dose of $100 \mathrm{mg} / \mathrm{kg} / \mathrm{body}$ weight 30 minutes after sodium valproate was administered orally to rats at a dose of $500 \mathrm{mg} / \mathrm{kg}$ for 14 days.

24 hours after the last RUT treatment (day 15), the rats were decapitated under mild sevoflurane anesthesia and their liver and kidney tissues and blood were collected. Tissues were stored in saline solution at $-80^{\circ} \mathrm{C}$ until used in biochemical analysis, Real-Time PCR and Western Blot techniques.

\section{Liver And Kidney Function Tests}

Blood taken from rats was centrifuged at $4000 \mathrm{rpm}$ at $+4^{\circ} \mathrm{C}$ and then ALT, AST, ALP, Urea and creatinine levels were analyzed in Mindray Perfect Plus 400 device. ALT, AST and ALP results were given as U/L. Urea and creatinine levels were presented as $\mathrm{mg} / \mathrm{dL}$. 


\section{Analysis of lipid peroxidation degree in liver and kidney tissues}

The degree of lipid peroxidation in liver and kidney tissues was determined by measuring the absorbance at 532 $\mathrm{nm}$ of the color formed by the reaction of malondialdehyde (MDA) with thiobarbituric acid (TBA). For this, the tissues were homogenized in $1.15 \%$ potassium chloride. The homogenates were then centrifuged at $3500 \mathrm{rpm}$ for 15 minutes. MDA levels were measured in the obtained supernatant with the method developed by Placer et al. (1966) [20].

\section{Analysis Of Antioxidant Markers In Liver And Kidney Tissues}

To determine the antioxidant status in liver and kidney tissues, SOD, CAT and GPx activities as well as GSH levels were analyzed. SOD activity was measured according to the method of Sun et al. (1988)[21]. CAT activity was determined by the method of Aebi (1984),[22] which measures the degradation rate of hydrogen peroxide per unit time. GPx activity was determined by the method developed by Lawrence and Burk (1976) [23]. GSH levels were measured by the method of Sedlak and Lindsay (1968).[24] Total protein content of testicular tissues was needed to calculate enzyme activities. The method of Lowry et al. (1951)[25] was used to determine this.

\section{Real-time Pcr Analysis In Liver And Kidney Tissues}

Total RNA isolation from liver and kidney tissues was performed with QIAzol Lysis Reagent (Qiagen, Cat: 79306, Germany). cDNA synthesis from total RNAs was performed with High-Capacity cDNA Reverse Transcription Kit (Applied Biosystems ${ }^{\mathrm{TM}}$ Cat: $4368814, \mathrm{USA}$ ). The obtained cDNAs were used to determine the mRNA transcript levels of the genes whose sequences are given in Table 1. In the RT-PCR stage, a mix was prepared with primers of NF-KB, TNF-a, Bax, Bcl-2, Caspase-3, IL-6, JAK2, STAT3, GRP78, ATF-6, IRE1, PERK, LC3A and LC3B genes, RNase free water and cDNAs, SYBR Green PCR Master Mix. Afterwards, analysis was performed with ROTOR-GENE Q (Qiagen, Germany) in triplicate. $\beta$-actin was used as a housekeeping gene, and the relative mRNA transcript levels were calculated from the obtained CT values using the $2^{-\Delta \Delta C T}$ method of Livak and Schmittgen (2001)[26]. 
Table 1

Primer sequences

\begin{tabular}{|c|c|c|c|}
\hline Gene & Sequences $\left(5^{\prime}-3^{\prime}\right)$ & Length (bp) & Accession No \\
\hline \multirow[t]{2}{*}{ NF-KB } & F: AGTCCCGCCCCTTCTAAAAC & 106 & NM_001276711.1 \\
\hline & R: CAATGGCCTCTGTGTAGCCC & & \\
\hline \multirow[t]{2}{*}{$\mathrm{IL}-1 \beta$} & F: ATGGCAACTGTCCCTGAACT & 197 & NM_031512.2 \\
\hline & R: AGTGACACTGCCTTCCTGAA & & \\
\hline \multirow[t]{2}{*}{ Bax } & F: TTTCATCCAGGATCGAGCAG & 154 & NM_017059.2 \\
\hline & R: AАTCATCCTCTGCAGCTCCA & & \\
\hline \multirow[t]{2}{*}{ Bcl-2 } & F: GACTTTGCAGAGATGTCCAG & 214 & NM_016993.2 \\
\hline & R: TCAGGTACTCAGTCATCCAC & & \\
\hline \multirow[t]{2}{*}{ Caspase-3 } & F: ACTGGAATGTCAGCTCGCAA & 270 & NM_012922.2 \\
\hline & R: GCAGTAGTCGCCTCTGAAGA & & \\
\hline \multirow[t]{2}{*}{ IL-6 } & F: AGCGATGATGCACTGTCAGA & 127 & NM_012589.2 \\
\hline & R: GGAACTCCAGAAGACCAGAGC & & \\
\hline \multirow[t]{2}{*}{ JAK2 } & F: TAGGTACGGAGTATCTCGTG & 215 & NM_031514.1 \\
\hline & R: TGGAGTTATAGACAGCCAGG & & \\
\hline \multirow[t]{2}{*}{ STAT3 } & F: TACCTGGAGCAGCTTCATCA & 153 & NM_012747.2 \\
\hline & R: GATCTCGCCCAAGAGGTTAT & & \\
\hline \multirow[t]{2}{*}{ ATF-6 } & F: TCAACTCAGCACGTTCCTGA & 130 & NM_001107196.1 \\
\hline & R: GACCAGTGACAGGCTTCTCT & & \\
\hline \multirow[t]{2}{*}{ PERK } & F: GATGCCGAGAATCATGGGAA & 198 & NM_031599.2 \\
\hline & R: AGATTCGAGAAGGGACTCCA & & \\
\hline \multirow[t]{2}{*}{ IRE1 } & F: GCAGTTCCAGTACATTGCCATTG & 163 & NM_001191926.1 \\
\hline & R: CAGGTCTCTGTGAACAATGTTGA & & \\
\hline \multirow[t]{2}{*}{ GRP78 } & F: CATGCAGTTGTGACTGTACCAG & 143 & NM_013083.2 \\
\hline & R: CTCTTATCCAGGCCATATGCAA & & \\
\hline \multirow[t]{2}{*}{ LC3A } & F: GACCATGTTAACATGAGCGA & 139 & NM_199500.2 \\
\hline & R: CCTGTTCATAGATGTCAGCG & & \\
\hline \multirow[t]{2}{*}{ LC3B } & F: GAGCTTCGAACAAAGAGTGG & 152 & NM_022867.2 \\
\hline & R: CGCTCATATTCACGTGATCA & & \\
\hline \multirow[t]{2}{*}{$\beta$-Actin } & F: CAGCCTTCCTTCTTGGGTATG & 360 & NM_031144.3 \\
\hline & R: AGCTCAGTAACAGTCCGCCT & & \\
\hline
\end{tabular}


Table 2. The effect of RUT and VALP administrations on oxidative stress markers in liver tissue and liver function tests in serum

\begin{tabular}{|c|c|c|c|c|c|}
\hline Paremeters & Control & RUT & VALP & VALP + RUT 50 & VALP + RUT 100 \\
\hline $\begin{array}{l}\text { MDA } \\
\text { (nmol/g } \\
\text { tissue) }\end{array}$ & $23.87 \pm 2.06$ & $23.23 \pm 1.64^{\mathrm{ns} / \# \# \#}$ & $43.16 \pm 2.12^{\star \star \star}$ & $37.20 \pm 1.59^{\star \star \star / \# \# \# ~}$ & $30.22 \pm 1.33^{\star \star \star / \# \# \#}$ \\
\hline $\begin{array}{l}\text { GSH } \\
\text { (nmol/g } \\
\text { tissue) }\end{array}$ & $5.29 \pm 0.26$ & $5.32 \pm 0.19^{\mathrm{ns} / \# \# \#}$ & $3.22 \pm 0.13^{\star \star \star}$ & $3.84 \pm 0.10^{\star \star \star / \# \# \#}$ & $4.75 \pm 0.14^{\star \star \star / \# \# \#}$ \\
\hline $\begin{array}{l}\text { SOD (U/g } \\
\text { protein) }\end{array}$ & $28.09 \pm 1.62$ & $29.05 \pm 1.61^{\mathrm{ns} / \# \# \#}$ & $15.82 \pm 1.88^{\star \star \star}$ & $19.36 \pm 0.69^{\star \star \star / \# \# ~}$ & $24.49 \pm 1.18^{\star \star / \# \# \# ~}$ \\
\hline $\begin{array}{l}\text { GPX (U/g } \\
\text { protein) }\end{array}$ & $33.26 \pm 2.27^{c}$ & $33.43 \pm 2.17^{\mathrm{ns} / \# \# \#}$ & $19.94 \pm 1.60^{\star \star \star}$ & $24.02 \pm 1.08^{\star \star \star / \# \#}$ & $29.80 \pm 0.74^{\star \star / \# \# \# ~}$ \\
\hline $\begin{array}{l}\text { CAT } \\
\text { (catal/g } \\
\text { protein) }\end{array}$ & $38.50 \pm 2.26$ & $38.03 \pm 1.56^{\mathrm{ns} / \# \# \#}$ & $26.55 \pm 1.35^{\star \star \star}$ & $31.79 \pm 1.48^{\star \star \star / \# \# \#}$ & $34.94 \pm 1.02^{\star \star / \# \# \# ~}$ \\
\hline ALT (U/L) & $24.29 \pm 2.75$ & $23.86 \pm 2.41 \mathrm{~ns} / \# \# \#$ & $102.43 \pm 6.45^{\star \star \star}$ & $65.86 \pm 5.34^{\star \star * / \# \# \#}$ & $37.14 \pm 4.81^{\star \star * / \# \# \#}$ \\
\hline AST (U/L) & $71.23 \pm 4.50$ & $67.59 \pm 3.72$ ns/\#\#\# & $213.14 \pm 8.23^{\star \star \star}$ & $147.86 \pm 6.36^{\star \star \star / \# \# \# ~}$ & $94.90 \pm 6.78^{\star \star \star / \# \# \# ~}$ \\
\hline ALP (U/L) & $85.57 \pm 5.47$ & $83.14 \pm 5.21 \mathrm{~ns} / \# \# \#$ & $267.14 \pm 10.12^{\star \star \star}$ & $124.71 \pm 8.34^{\star \star \star / \# \# \# ~}$ & $106.43 \pm 5.74^{\star \star \star / \# \# \# ~}$ \\
\hline
\end{tabular}

Statistical significance $(* P \otimes 0.05, \star \star p<0.01, * \star \star p<0.001, \# P \otimes 0.05, \# \# p<0.01, \# \# \# p<0.001$, ns; not significant) was analyzed using One Way ANOVA

\section{Western Blot Analysis Of Liver And Kidney Tissues}

Tissues were homogenized for western blotting in RIPA lysis buffer (sc-24948, Santa Cruz Biotechnology, Inc., Texas, USA) containing protease inhibitor cocktail and sodium orthovanadate. Homogenates were centrifuged at $16000 \mathrm{~g}$ for 20 minutes. Protein concentrations were measured using the PierceTM BCA Protein Assay Kit (Rockford, IL, USA). Laemmli buffer was added to the supernatant obtained. Samples containing $30 \mu \mathrm{g}$ of protein were loaded into each well and separated on $10 \%$ sodium dodecyl sulfate polyacrylamide gel (SDS-PAGE). It was then transferred from the gel to polyvinylidene fluoride (PVDF) membranes. Proteins transferred to the PVDF membrane were blocked with $5 \%$ BSA for 1.5 hours at room temperature, and then washed with tris buffer salt (TBS-T) containing 0.1\% Tween 203 times at 5 minutes intervals. After adding Bax, Caspase-3, Bcl-2, Beclin-1, cytochrome-c, NF-KB, ERK, JNK, p-JNK, p-ERK and $\beta$-aktin primary antibodies, incubation was carried out at $+4{ }^{\circ} \mathrm{C}$ overnight. Then, washing was done with TBS-T 5 times for 5 minutes. The membrane was then incubated in goat anti-mouse IgG secondary antibodies (1:1000 dilution, Santa Cruz Biotechnology, Inc, Texas, USA) diluted 1:2000 with TBS-T at room temperature for 1.5 hours. Washing was done 5 times with TBS-T. Immunoblot bands transferred to PVDF membranes were visualized on ImageQuant LAS 500 (GE Healthcare Bio-Sciences AB, Uppsala, Sweden) using ClarityTM Western ECL Substrate (Bio-Rad, Hercules, USA) as substrate. The intensity of the bands was measured using the Image J program (NIH, Bethesda, USA). 


\section{Statistical analysis}

Statistical evaluation of the analysis performed in liver and kidney tissues was done in IBM SPSS program. Oneway ANOVA and Tukey's post hoc tests were used to determine whether there was a statistical difference between the experimental groups (ns; not significant, ${ }^{\#} \mathrm{P} \otimes 0.05,{ }^{\# \#} p<0.01,{ }^{\# \#} p<0.001,{ }^{*} \mathrm{P} \otimes 0.05,{ }^{\star *} p<0.01,{ }^{\star * \star} p<0.001$ ). The results were presented as mean $\pm S D$.

\section{Results}

\section{The effect of sodium valproate and rutin administrations on serum ALT, AST, ALP, urea and creatinine levels}

Serum ALT, ALP, and AST levels were analyzed to assess liver function, and the results are presented in Table 2. The results show that VLP administration caused liver damage and significantly increased serum ALT, AST and ALP levels compared to the control group $(\mathrm{P}<0.001)$. However, it was determined that RUT treatment protected the liver from the destructive effect of VLP and dose-dependently reduced serum ALT, AST and ALP levels compared to the VLP group $(P<0.001)$.

According to the results given in Table 3, it was determined that VLP administration increased serum urea and creatinine levels compared to the control group, while RUT treatment decreased serum urea and creatinine levels $(P<0.001)$.

Table 3

The effect of RUT and VALP administrations on oxidative stress markers in kidney tissue and renal function tests in serum

\begin{tabular}{|c|c|c|c|c|c|}
\hline Paremeters & Control & RUT & VALP & VALP + RUT 50 & VALP + RUT 100 \\
\hline $\begin{array}{l}\text { MDA (nmol/g } \\
\text { tissue) }\end{array}$ & $36.34 \pm 1.22$ & $35.70 \pm 1.58^{\mathrm{ns} / \# \# \#}$ & $61.05 \pm 2.14^{\star \star \star}$ & 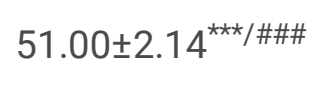 & $42.00 \pm 1.69^{\star \star \star / \# \# \# ~}$ \\
\hline $\begin{array}{l}\text { GSH (nmol/g } \\
\text { tisseu) }\end{array}$ & $4.24 \pm 0.15$ & $4.37 \pm 0.14^{\mathrm{ns} / \# \# \#}$ & $2.54 \pm 0.11^{\star \star \star}$ & $3.09 \pm 0.12^{\star \star \star / \# \# \# ~}$ & $3.86 \pm 0.08^{\star \star \star / \# \# \# ~}$ \\
\hline $\begin{array}{l}\text { SOD }(U / g \\
\text { protein) }\end{array}$ & $22.89 \pm 1.22$ & $\begin{array}{l}24.68 \pm 0.83 \\
\mathrm{~ns} / \# \# \#\end{array}$ & $14.06 \pm 1.69^{\star \star \star}$ & $16.56 \pm 1.06^{\star \star \star / \# \#}$ & $19.72 \pm 1.01^{\star \star \star / \# \# \# ~}$ \\
\hline GPx (U/g protein) & $27.27 \pm 1.80$ & $27.07 \pm 1.65^{\mathrm{ns} / \# \# \#}$ & $15.14 \pm 0.77^{\star \star \star}$ & $17.66 \pm 1.06^{\star \star \star / \#}$ & $23.61 \pm 1.42^{\star \star \star / \# \# \# ~}$ \\
\hline $\begin{array}{l}\text { CAT (catal/g } \\
\text { protein) }\end{array}$ & $32.33 \pm 1.58$ & $32.92 \pm 1.69^{\mathrm{ns} / \# \# \#}$ & $16.91 \pm 1.55^{\star \star \star}$ & $27.01 \pm 1.52^{\star \star \star / \# \# \#}$ & $28.69 \pm 0.97^{\star \star / \# \# \# ~}$ \\
\hline Urea (mg/dL) & $33.57 \pm 1.72$ & $33.57 \pm 1.90^{\mathrm{ns} / \# \# \#}$ & $54.43 \pm 2.30^{\star \star \star}$ & $45.57 \pm 1.72^{\star \star \star / \# \# \# ~}$ & $42.34 \pm 2.05^{\star \star \star / \# \# \# ~}$ \\
\hline $\begin{array}{l}\text { Creatinin } \\
(\mathrm{mg} / \mathrm{dL})\end{array}$ & $0.36 \pm 0.03$ & $0.34 \pm 0.04^{\mathrm{ns} / \# \# \#}$ & $1.09 \pm 0.06^{\star \star \star}$ & $0.87 \pm 0.04^{\star \star \star / \# \# \# ~}$ & $0.45 \pm 0.05^{\star \star / \# \# \# ~}$ \\
\hline \multicolumn{6}{|c|}{$\begin{array}{l}\text { Statistical significance }(* P \otimes 0.05, * \star p<0.01, \star \star \star p<0.001, \# P \otimes 0.05, \# \# p<0.01, \# \# \#<0.001, n s \text {; not significant) was analyzed using One Way } \\
\text { ANOVA }\end{array}$} \\
\hline
\end{tabular}




\section{The effect of sodium valproate and rutin administrations on oxidative/antioxidant status in liver and kidney tissues}

Markers showing the oxidant/antioxidant status of liver and kidney tissues are presented in Table 2 and Table 3. Accordingly, in both liver and kidney tissue, when compared to the control group, VLP suppressed the activities of antioxidant enzymes (SOD, CAT, GPx), depleted GSH stores and increased MDA levels $(P<0.001)$. This shows that VLP can cause tissue damage by triggering oxidative stress in liver and kidney tissues. However, it was determined that RUT treatment increased the antioxidant enzyme activities and GSH levels and decreased MDA levels in both tissues in a dose-dependent manner. Thus, it was determined that it reduced the oxidative damage caused by VLP.

\section{The effect of sodium valproate and rutin administrations on inflammatory status in liver and kidney tissues}

To determine the effects of VLP and RUT administrations on the inflammatory state in liver and kidney tissues, mRNA transcript levels of NF-KB, TNF- $\alpha$ and IL-6 cytokines were analyzed. The results are presented in Fig. 1. Accordingly, it was observed that VLP application triggered inflammation by causing an increase in NF-KB, TNF-a and IL-6 mRNA transcript levels in both liver and kidney $(P<0.001)$. It was determined that only RUT administration did not create a significant difference compared to the control group. Also, it was observed that RUT treatment with VLP decreased the expressions of NF-KB, TNF- $\alpha$ and IL- 6 cytokines in both tissues, however, there was a difference between doses only in TNF-a expression levels (kidney; $P<0.05$, liver; $P<0.001$ ).

Protein levels of NF-KB in liver and kidney tissue were also analyzed and the results are presented in Fig. 2. The data showed that VLP significantly increased NF-KB protein levels in liver and kidney tissue compared to the control group $(P<0.001)$. Similar to the mRNA transcript levels in the kidney tissue, the protein levels of NF-KB decreased after RUT administration compared to the VLP group $(P<0.001)$, but there was no significant difference between the doses. In liver tissue, it was determined that RUT treatment decreased NF-KB protein levels in a dosedependent manner compared to the VLP group $(P<0.001)$.

\section{Effect of sodium valproate and rutin administrations on jak2/stat3 pathway in liver and kidney tissues}

In the study, after VLP and RUT applications were applied to rats, the JAK2/STAT3 pathway in liver and kidney tissues was investigated by RT-PCR method. The results are presented in Fig. 3. According to the data obtained, it was observed that VLP activates the pathway by increasing the levels of JAK2 and STAT3 mRNA transcripts in the liver and kidney $(\mathrm{P}<0.001)$. However, it was determined that RUT administration suppressed both JAK2 and STAT3 expression in kidney tissue in a dose-dependent manner (JAK2; $\mathrm{P}<0.001$, STAT3; $\mathrm{P}<0.01$ ). In liver tissue, it was determined that RUT treatment decreased STAT3 expression dose-dependently $(P<0.001)$, but there was no significant difference between doses in JAK2 expression.

\section{The effect of sodium valproate and rutin administrations on apoptotic status in liver and kidney tissues}

The mRNA transcript levels of Bax, $\mathrm{Bcl}-2$ and caspase-3 in liver and kidney tissues of rats are presented in Fig. 4 . RT-PCR analysis show that VLP triggers Bax and caspase-3 expressions and suppresses $\mathrm{Bcl}-2$ expression, causing apoptosis in liver and kidney $(P<0.001)$. On the other hand, treating animals with RUT provided significant tissue protection by disrupting the apoptotic pathway in the liver and kidney. While it was observed that Bax expression decreased in a dose-dependent manner in kidney tissue $(P<0.05)$, there was no difference between doses in Caspase-3 and Bcl-2 expressions. In the liver, on the other hand, it was determined that the expression levels of three genes changed in a dose-dependent manner (Bax and Caspase-3; $\mathrm{P}<0.001, \mathrm{Bcl}-2 ; \mathrm{P}<0.01$ ). 
Apoptotic markers were also analyzed by Western Blotting. The results are summarized in Fig. 5. Accordingly, it was determined that VLP significantly increased Bax, Caspase-3 and cytochrome-c levels in both tissues and decreased Bcl-2 levels in correlation with RT-PCR results $(P<0.001)$. After the treatment of animals with RUT, it was observed that these markers decreased significantly in the liver tissues, while it was determined that high dose were more effective on caspase-3 and Bcl-2 ( $\mathrm{P}<0.01)$. In kidney tissue, it was observed that caspase-3 levels did not make a difference between doses, while high dose were more effective on other parameters (Cytochrome $C$; $\mathrm{P}<0.05, \mathrm{Bax} ; \mathrm{P}<0.01, \mathrm{Bcl}-2 ; \mathrm{P}<0.001)$.

Apoptosis status was also assessed by the pERK/ERK and pJNK/JNK ratios analyzed by western blotting (Fig. 6). It was determined that VLP given to rats activates the apoptotic pathway by increasing the pERK/ERK and pJNK/JNK ratios in liver and kidney tissue compared to the control group $(P<0.001)$. However, it was observed that RUT treatment decreased the pERK/ERK and pJNK/JNK ratios in both tissues. While it was determined that high dose was more effective on pERK/ERK ratio in kidney tissue $(P<0.05)$, there was no significant difference between doses in liver tissue. The situation was similar for the pJNK/JNK ratio. While there was no difference between the doses in the liver tissue, it was observed that the $100 \mathrm{mg} / \mathrm{kg}$ dose was more effective in the kidney $(\mathrm{P}<0.001)$.

\section{The effect of sodium valproate and rutin administrations on endoplasmic reticulum stress in liver and kidney tissues}

The mRNA transcript levels of PERK, IRE1, ATF-6 and GRP78 genes, which show ER stress in liver and kidney tissues of rats, are given in Figure 7. It was determined that VLP caused ER stress by increasing ATF-6, GRP78, IRE1, and PERK transcript levels in both tissues $(P<0.001)$. On the other hand, it was observed that RUT decreased GRP78 levels in liver tissue in a dose-dependent manner compared to the VLP group $(P<0.05)$, while there was no difference in ATF-6 and PERK levels between doses. It was determined that the mRNA transcript level of IRE did not differ in the $50 \mathrm{mg} / \mathrm{kg}$ RUT group compared to the VLP group, however, $100 \mathrm{mg} / \mathrm{kg}$ dose reduced IRE1 levels compared to the VLP group $(\mathrm{P}<0.01)$. It was observed that IRE1 and GRP78 in kidney tissue were dose-dependently decreased compared to the VLP group $(P<0.001)$. It was determined that the mRNA transcript levels of PERK did not differ from the VLP group in the low-dose RUT group. Although there was a decrease in ATF-6 levels in both doses compared to the VLP group, no difference could be detected between the doses.

\section{The effect of sodium valproate and rut administrations on autophagy in liver and kidney tissues}

Autophagic status in liver and kidney tissues was evaluated by analyzing mRNA transcript levels of LC3A and LC3B by RT-PCR and protein levels of Beclin- 1 by Western blot method. The results show that VLP induces autophagy by increasing mRNA transcript levels of LC3A and LC3B and protein levels of Beclin-1 in liver and kidney tissue $(\mathrm{P}<0.001)$. While it was observed that the mRNA transcript levels of LC3A and LC3B decreased in a dose-dependent manner in kidney tissue $(\mathrm{P}<0.001)$, only LC3B decreased in a dose-dependent manner in liver tissue $(P<0.01)$. It is also among the data obtained that LC3A mRNA transcript levels in liver tissue do not differ between low dose and VLP group. In addition, it was observed that RUT administration dose-dependently decreased Beclin-1 protein levels in both tissues $(P<0.001)$ and provided significant protection against VLPinduced autophagy. All results are summarized in Fig. 8 and Fig. 9. 


\section{Discussion}

VLP, which is used in the treatment of many psychiatric disorders, causes undesirable effects in some organs, including the liver and kidney [1, 3]. In studies conducted to investigate the basic mechanism of these effects, it has been reported that VLP mainly causes oxidative stress and subsequently inflammation and apoptosis, causing tissue damage $[3,27]$. Based on this, the potential protective effects of RUT against VLP-induced liver and kidney damage were investigated through pathways involved in oxidative stress, inflammation, apoptosis and autophagy.

The liver is the main organ involved in the detoxification of various toxic agents. Therefore, its function changes significantly in many toxicities. ALT, AST and ALP enzymes are routinely used markers for the determination of liver damage $[28,29]$. Previous studies have reported that VLP increases plasma levels of these cellular enzymes by inducing liver damage [1]. In the presented study, it was observed that ALT, AST and ALP enzymes increased with VLP administration, approaching the control group levels after RUT treatment. These results show that RUT reduces VLP-induced hepatic degradation. In the study, urea and creatinine levels were measured to detect kidney damage. [28] The results show that VLP administration significantly increases urea and creatinine levels in the blood, affecting kidney function. It has been shown in many studies that various toxic agents cause kidney damage and cause an increase in urea and creatinine levels [30,31]. In addition, it was determined that RUT treatment reduced urea and creatinine levels by attenuating VLP-induced kidney damage in our study, similar to previous studies with different toxic agents $[19,32]$.

Toxic compounds cause an increase in free oxygen radicals (ROS) in tissues and organs. Oxidative stress occurs as a result of insufficient antioxidant defense mechanism in the body against increasing ROS and/or suppression of their activities by toxic agents [33]. ROS activate several mechanisms by damaging cell membranes and macromolecules in cells, resulting in inflammation and cell death [34]. Oxidative stress is considered as the basic mechanism of tissue damage caused by toxic substances [35]. It has been reported that oxidative stress is one of the main factors in VLP toxicity. Lipid peroxidation is an important indicator of oxidative stress. The main parameter used to determine the degree of lipid peroxidation is the measurement of MDA levels $[33,36]$. Previous studies have reported that VLP administration increases MDA levels by causing lipid peroxidation [1, 27]. In the present study, it was determined that VLP caused lipid peroxidation, possibly by increasing ROS production, which in turn increased MDA levels. It is thought that RUT scavenges ROS formed by VLP through its hydroxyl groups and reduces lipid peroxidation.

Antioxidant defense mechanisms include enzymatic and non-enzymatic antioxidant substances. GSH is a strong non-enzymatic antioxidant compound in tripeptide structure. In addition, SOD, CAT and GPx are enzymatic antioxidants in defense against ROS [37]. Decreases in the levels of these antioxidant substances cause failure in the fight against ROS and a significant increase in oxidative stress [38]. This has been clearly stated in many previous studies $[1,39,40]$. In the presented study, it was determined that VLP inhibits SOD, CAT and GPx enzymes, decreases GSH stores, and thus causes tissue damage due to increased oxidative stress in liver and kidney tissues. RUT, on the other hand, provided significant protection against oxidative stress by increasing the levels of these antioxidants.

Inflammation is one of the main consequences of oxidative stress. Increased oxidative stress triggers the expression of NF-KB, a transcription factor. NF-KB is involved in the regulation of pro-inflammatory cytokines [13].

Page $10 / 21$ 
NF-KB is separated from IKB in the cytosol and translocates to the nucleus and stimulates the release of cytokines such as TNF-a and IL-6, which have an important role in inflammation. [12, 41, 42]. In a previous study, it was reported that VLP triggered the expression of NF-KB in the liver, causing an increase in mRNA transcript levels of IL$1 \beta$ and TNF- $\alpha$ and initiating the inflammatory process [5]. In the presented study, it was observed that VLP caused an increase in both mRNA transcript levels and protein levels of NF-KB in liver and kidney tissues. It was determined that it probably caused inflammation by up-regulating TNF-a and IL-6 gene expressions in both tissues. However, it is thought that RUT reduces NF-KB expression by attenuating oxidative stress and thus protects against inflammation by suppressing TNF- $a$ and IL- 6 genes.

One of the pathways that have an important role in the inflammatory process is the JAK2/STAT3 pathway and this pathway is regulated by IL-6. STAT3 is activated by IL-6. Activated STAT3 triggers the expression of JAK2 [34, 43]. Previous studies have reported that inhibiting the IL-6/JAK2/STAT3 pathway will prevent inflammation and thus protect tissues against possible damage $[44,45]$. In the present study, it was observed that there was an increase in the levels of JAK2 and STAT3 mRNA transcripts in liver and kidney tissues in correlation with IL-6. However, it was determined that RUT application protected the liver and kidney tissues from inflammation and decreased the expressions of JAK2 and STAT3.

The endoplasmic reticulum is of vital importance because of its roles in protein folding, protein maturation, and calcium homeostasis [46]. Some physiological conditions or environmental factors can lead to disruption of ER homeostasis and, as a result, accumulation of unfolded or misfolded proteins in the ER lumen [47]. To cope with ER stress, cells develop an unfolded protein response (UPR). However, the increase in the intensity of the UPR or the prolongation of the UPR cause ER stress and cause the cells to undergo apoptosis [48]. In mammals, ER transmembrane protein sensors IRE1, PERK and ATF-6 accompany the UPR and are considered important indicators of ER stress [49]. Also, GRP78 is an important chaperone involved in the regulation of ER stress [34]. In the present study, it is thought that VLP increases PERK, IRE1, ATF-6 and GRP78 expressions in liver and kidney tissues and this triggers the UPR. In addition, the increase in the levels of apoptotic markers suggests that ER stress occurs severely. On the other hand, it was observed that RUT treatment alleviated ER stress and downregulated PERK, IRE1, ATF-6 and GRP78 expressions. Previous studies have reported that natural antioxidants, including RUT, can alleviate ER stress [50, 51].

The Bcl-2 family consists of pro-apoptotic and anti-apoptotic proteins that determine cell survival decisions. Bax, Bak, Bad and Bik in this family trigger apoptosis, while $\mathrm{Bcl}-2$ is responsible for inhibiting apoptosis. The balance between these proteins determines the fate of cells in the apoptotic pathway. Caspase 9 is activated when an increase in the Bax/Bcl-2 ratio occurs, increasing caspase 3 expression [52]. In addition, increased cytochrome c levels also trigger apoptosis by causing activation of caspase 3 protein [28]. Previous studies have reported that various toxic agents cause apoptosis in various tissues, including liver and kidney, by increasing cytochrome $c$, Bax, and Caspase-3 levels and decreasing Bcl-2 levels, resulting in serious damage to tissues $[28,29,53]$. In the presented study, RT-PCR and/or western blot analyzes show that VLP increases the protein levels of Bax and cytochrome $\mathrm{c}$ in liver and kidney tissues and causes caspase-3 activity. It was also seen that VLP caused a decrease in Bcl-2 levels. Together, it was determined that VLP could affect the function of organs by causing apoptosis in liver and kidney tissues. However, RUT provided significant protection against apoptosis by decreasing cytochrome c, Bax and caspase-3 levels and increasing Bcl-2 levels.

JNK and ERK are members of the MAPK family. While JNK activates apoptotic signaling through up-regulation of proapoptotic genes, [54] ERK causes cytochrome c release or caspase-8 activation and can stimulate intrinsic or 
extrinsic apoptotic pathways [55]. In the study, it was thought that liver and kidney tissues could be protected from VLP toxicity by interrupting the pERK and pJNK pathways. The data obtained show that the protein levels of pERK and pJNK induced by VLP are significantly reduced after RUT treatment. In a previous study, it was reported that significant protection against tissue damage was provided by interrupting the ERK/JNK pathway activated by tamoxifen [56].

Autophagy is another physiological event induced by oxidative stress [57]. Occurrence of autophagy at high levels triggers cell death in various tissues and results in tissue function loss [58]. Beclin-1, LC3A and LC3B are involved in the autophagic process and are important markers used to determine the degree of autophagy In the present study, it is thought that VLP causes autophagy by increasing beclin-1, LC3A and LC3B levels in liver and kidney tissues, and this contributes significantly to the deterioration of liver and kidney functions. On the other hand, it was observed that RUT showed an anti-autophagic effect and decreased beclin-1, LC3A and LC3B levels. Previous studies have reported that naturally occurring antioxidants reduce autophagy, which is increased by different toxic compounds $[58,59]$.

\section{Conclusion}

When all the results were evaluated together, it was seen that VLP exacerbated ER stress by triggering oxidative stress, activating the ERK/JNK pathway and ultimately causing apoptosis. Also, it was determined that VLP initiated the NF-KB cascade, causing the activation of pro-inflammatory cytokines and the JAK2/STAT3 pathway, thus triggering inflammation. VLP caused autophagy in liver and kidney tissues by increasing beclin-1, LC3A and LC3B levels. However, the antioxidant properties of RUT initially attenuated oxidative stress, and the resulting ER stress, inflammation, apoptosis and autophagy attenuated. These effects of RUT are also confirmed by markers, which are the main indicators of liver and kidney damage.

\section{Declarations}

\section{Funding}

This study was supported by Ataturk University, Foundation of Scientific Researches Projects (Project number: TSA-2021-9188).

\section{Conflicts of interest/Competing interests}

The authors have no conflict of interest.

\section{Availability of data and material}

Not applicable

\section{Code availability}

Not applicable

\section{Authors' contributions}


Fatih Mehmet Kandemir: Conceptualization, Methodology, Formal analysis, Investigation, Writing - Review \& Editing. Mustafa lleriturk: Data Curation, Methodology, Conceptualization. Cihan Gur: Data Curation, Methodology, Conceptualization.

\section{Ethics approval}

Ethical approval was obtained from Atatürk University Animal Experiments Local Ethics Committee for the study (Approval No: 2021-2-32).

\section{Consent to participate}

Not applicable

\section{Consent for publication}

The author gives her consent for the publication of this manuscript.

\section{References}

[1] Zhou L, Chen L, Zeng X, Liao J, Ouyang D. Ginsenoside compound K alleviates sodium valproate-induced hepatotoxicity in rats via antioxidant effect, regulation of peroxisome pathway and iron homeostasis. Toxicology and applied pharmacology. 2020;386:114829.

[2] Koroglu OF, Gunata M, Vardi N, Yildiz A, Ates B, Colak C, et al. Protective effects of naringin on valproic acidinduced hepatotoxicity in rats. Tissue and Cell. 2021;72:101526.

[3] Adewole KE, Attah AF, Osawe SO. Exploring phytotherapeutic approach in the management of valproic acidinduced toxicity. Advances in Traditional Medicine. 2021:1-21.

[4] Chaudhary S, Ganjoo P, Raiusddin S, Parvez S. Nephroprotective activities of quercetin with potential relevance to oxidative stress induced by valproic acid. Protoplasma. 2015;252:209-17.

[5] Oztopuz O, Turkon H, Buyuk B, Coskun O, Sehitoglu MH, Ovali MA, et al. Melatonin ameliorates sodium valproate-induced hepatotoxicity in rats. Molecular biology reports. 2020;47:317-25.

[6] Galaly SR, Abdella EM, Mohammed HM. Effects of royal jelly on genotoxicity and nephrotoxicity induced by valproic acid in albino mice. Beni-Suef University journal of basic and applied sciences. 2014;3:1-15.

[7] Tong V, Teng XW, Chang TK, Abbott FS. Valproic acid I: time course of lipid peroxidation biomarkers, liver toxicity, and valproic acid metabolite levels in rats. Toxicological Sciences. 2005;86:427-35.

[8] Kiang TK, Teng XW, Surendradoss J, Karagiozov S, Abbott FS, Chang TK. Glutathione depletion by valproic acid in sandwich-cultured rat hepatocytes: Role of biotransformation and temporal relationship with onset of toxicity. Toxicology and applied pharmacology. 2011;252:318-24.

[9] Jin J, Xiong T, Hou X, Sun X, Liao J, Huang Z, et al. Role of Nrf2 activation and NF-KB inhibition in valproic acid induced hepatotoxicity and in diammonium glycyrrhizinate induced protection in mice. Food and chemical toxicology. 2014;73:95-104. 
[10] Jahan S, Munawar A, Razak S, Anam S, Ain QU, Ullah H, et al. Ameliorative effects of rutin against cisplatininduced reproductive toxicity in male rats. BMC urology. 2018;18:1-11.

[11] Kandemir FM, Kucukler S, Caglayan C, Gur C, Batil AA, Gülçin I. Therapeutic effects of silymarin and naringin on methotrexate-induced nephrotoxicity in rats: Biochemical evaluation of anti-inflammatory, antiapoptotic, and antiautophagic properties. Journal of food biochemistry. 2017;41:e12398.

[12] Yardim A, Kandemir FM, Ozdemir S, Kucukler S, Comakli S, Gur C, et al. Quercetin provides protection against the peripheral nerve damage caused by vincristine in rats by suppressing caspase 3, NF-KB, ATF- 6 pathways and activating Nrf2, Akt pathways. Neurotoxicology. 2020;81:137-46.

[13] Kucukler S, Benzer F, Yildirim S, Gur C, Kandemir FM, Bengu AS, et al. Protective effects of chrysin against oxidative stress and inflammation induced by lead acetate in rat kidneys: a biochemical and histopathological approach. Biological Trace Element Research. 2021;199:1501-14.

[14] Kandemir FM, Caglayan C, Aksu EH, Yildirim S, Kucukler S, Gur C, et al. Protective effect of rutin on mercuric chloride-induced reproductive damage in male rats. Andrologia. 2020;52:e13524.

[15] Caglayan C, Kandemir FM, Darendelioğlu E, Yıldırım S, Kucukler S, Dortbudak MB. Rutin ameliorates mercuric chloride-induced hepatotoxicity in rats via interfering with oxidative stress, inflammation and apoptosis. Journal of Trace Elements in Medicine and Biology. 2019;56:60-8.

[16] Çelik H, Kandemir FM, Caglayan C, Özdemir S, Çomaklı S, Kucukler S, et al. Neuroprotective effect of rutin against colistin-induced oxidative stress, inflammation and apoptosis in rat brain associated with the CREB/BDNF expressions. Molecular biology reports. 2020;47:2023-34.

[17] Aktaş MS, Kandemir FM, Özkaraca M, Hanedan B, Kırbaş A. Protective effects of rutin on acute lung injury induced by oleic acid in rats. Kafkas Univ Vet Fak Derg. 2017;23:443-51.

[18] Semwal R, Joshi SK, Semwal RB, Semwal DK. Health benefits and limitations of rutin-A natural flavonoid with high nutraceutical value. Phytochemistry Letters. 2021;46:119-28.

[19] Caglayan C, Kandemir FM, Yildirim S, Kucukler S, Eser G. Rutin protects mercuric chloride-induced nephrotoxicity via targeting of aquaporin 1 level, oxidative stress, apoptosis and inflammation in rats. Journal of Trace Elements in Medicine and Biology. 2019;54:69-78.

[20] Placer ZA, Cushman LL, Johnson BC. Estimation of product of lipid peroxidation (malonyl dialdehyde) in biochemical systems. Analytical biochemistry. 1966;16:359-64.

[21] Sun Y, Oberley LW, Li Y. A simple method for clinical assay of superoxide dismutase. Clinical chemistry. $1988 ; 34: 497-500$.

[22] Aebi H. [13] Catalase in vitro. Methods in enzymology. 1984;105:121-6.

[23] Lawrence RA, Burk RF. Glutathione peroxidase activity in selenium-deficient rat liver. Biochemical and biophysical research communications. 1976;71:952-8. 
[24] Sedlak J, Lindsay RH. Estimation of total, protein-bound, and nonprotein sulfhydryl groups in tissue with Ellman's reagent. Analytical biochemistry. 1968;25:192-205.

[25] Lowry OH, Rosebrough NJ, Farr AL, Randall RJ. Protein measurement with the Folin phenol reagent. Journal of biological chemistry. 1951;193:265-75.

[26] Livak KJ, Schmittgen TD. Analysis of relative gene expression data using real-time quantitative PCR and the 2- $\triangle \Delta$ CT method. methods. 2001;25:402-8.

[27] Gad AM. Study on the influence of caffeic acid against sodium valproate-induced nephrotoxicity in rats. Journal of biochemical and molecular toxicology. 2018;32:e22175.

[28] Kandemir FM, Yıldırım S, Kucukler S, Caglayan C, Darendelioğlu E, Dortbudak MB. Protective effects of morin against acrylamide-induced hepatotoxicity and nephrotoxicity: A multi-biomarker approach. Food and Chemical Toxicology. 2020;138:111190.

[29] Küçükler S, Çomaklı S, Özdemir S, Çağlayan C, Kandemir FM. Hesperidin protects against the chlorpyrifosinduced chronic hepato-renal toxicity in rats associated with oxidative stress, inflammation, apoptosis, autophagy, and up-regulation of PARP-1/VEGF. Environmental Toxicology. 2021.

[30] Caglayan C, Kandemir FM, Darendelioğlu E, Küçükler S, Ayna A. Hesperidin protects liver and kidney against sodium fluoride-induced toxicity through anti-apoptotic and anti-autophagic mechanisms. Life Sciences. 2021:119730.

[31] Kandemir FM, Caglayan C, Darendelioğlu E, Küçükler S, İzol E, Kandemir Ö. Modulatory effects of carvacrol against cadmium-induced hepatotoxicity and nephrotoxicity by molecular targeting regulation. Life Sciences. 2021;277:119610.

[32] Rakshit S, Shukla P, Verma A, Kumar Nirala S, Bhadauria M. Protective role of rutin against combined exposure to lipopolysaccharide and D-galactosamine-induced dysfunctions in liver, kidney, and brain: Hematological, biochemical, and histological evidences. Journal of Food Biochemistry. 2021;45:e13605.

[33] Gür CK, F.M.Genç, A. Bortezomib ile Kalp Hasarı Oluşturulan Ratlarda Berberinin Oksidatif ve Nitrozatif Stres Üzerine Etkisi. Türk Doğa ve Fen Dergisi.9:118-26.

[34] Gur C, Kandemir O, Kandemir FM. Investigation of the effects of hesperidin administration on abamectininduced testicular toxicity in rats through oxidative stress, endoplasmic reticulum stress, inflammation, apoptosis, autophagy, and JAK2/STAT3 pathways. Environmental Toxicology.

[35] Abdel-Daim MM, Abd Eldaim MA, Hassan AG. Trigonella foenum-graecum ameliorates acrylamide-induced toxicity in rats: Roles of oxidative stress, proinflammatory cytokines, and DNA damage. Biochemistry and Cell Biology. 2015;93:192-8.

[36] Semis HS, Gur C, lleriturk M, Kandemir FM, Kaynar O. Evaluation of Therapeutic Effects of Quercetin Against Achilles Tendinopathy in Rats via Oxidative Stress, Inflammation, Apoptosis, Autophagy, and Metalloproteinases. The American Journal of Sports Medicine. 2021:03635465211059821. 
[37] El-Shenawy NS. Effects of insecticides fenitrothion, endosulfan and abamectin on antioxidant parameters of isolated rat hepatocytes. Toxicology in vitro. 2010;24:1148-57.

[38] Meligi N, Hassan H. Protective effects of Eruca sativa (rocket) on abamectin insecticide toxicity in male albino rats. Environmental Science \& Pollution Research. 2017;24.

[39] Arora D, Siddiqui MH, Sharma PK, Singh SP, Tripathi A, Mandal P, et al. Evaluation and physiological correlation of plasma proteomic fingerprints for deltamethrin-induced hepatotoxicity in Wistar rats. Life sciences.

2016;160:72-83.

[40] Kucukler S, Caglayan C, Darendelioğlu E, Kandemir FM. Morin attenuates acrylamide-induced testicular toxicity in rats by regulating the NF-KB, Bax/Bcl-2 and PI3K/Akt/mTOR signaling pathways. Life Sciences. 2020;261:118301.

[41] Semis HS, Gur C, Ileriturk M, Kaynar O, Kandemir FM. Investigation of the anti-inflammatory effects of caffeic acid phenethyl ester in a model of $\lambda$-Carrageenan-induced paw edema in rats. Human $\&$ Experimental Toxicology. 2021:09603271211054436.

[42] Jin H, Peng X, He Y, Ruganzu JB, Yang W. Tanshinone IIA suppresses lipopolysaccharide-induced neuroinflammatory responses through NF-KB/MAPKs signaling pathways in human U87 astrocytoma cells. Brain Research Bulletin. 2020;164:136-45.

[43] Semis HS, Kandemir FM, Kaynar O, Dogan T, Arikan SM. The protective effects of hesperidin against paclitaxel-induced peripheral neuropathy in rats. Life Sciences. 2021:120104.

[44] Zhou G-Y, Yi Y-X, Jin L-X, Lin W, Fang P-P, Lin X-Z, et al. The protective effect of juglanin on fructose-induced hepatitis by inhibiting inflammation and apoptosis through TLR4 and JAK2/STAT3 signaling pathways in fructose-fed rats. Biomedicine \& Pharmacotherapy. 2016;81:318-28.

[45] Li Q, Yang H, Wang W, Li N, Zou X, Li Y, et al. Brassica rapa Polysaccharides Ameliorate CCl4-Induced Acute Liver Injury in Mice through Inhibiting Inflammatory Apoptotic Response and Oxidative Stress. Chemistry \& biodiversity. 2020;17:e1900534.

[46] Yang Y, Lin X, Huang H, Feng D, Ba Y, Cheng X, et al. Sodium fluoride induces apoptosis through reactive oxygen species-mediated endoplasmic reticulum stress pathway in Sertoli cells. Journal of Environmental Sciences. 2015;30:81-9.

[47] Zhang S, Jiang C, Liu H, Guan Z, Zeng Q, Zhang C, et al. Fluoride-elicited developmental testicular toxicity in rats: roles of endoplasmic reticulum stress and inflammatory response. Toxicology and applied pharmacology. 2013;271:206-15.

[48] Niu Q, Chen J, Xia T, Li P, Zhou G, Xu C, et al. Excessive ER stress and the resulting autophagic flux dysfunction contribute to fluoride-induced neurotoxicity. Environmental Pollution. 2018;233:889-99.

[49] Deng H, Kuang P, Cui H, Chen L, Luo Q, Fang J, et al. Sodium fluoride (NaF) induces the splenic apoptosis via endoplasmic reticulum (ER) stress pathway in vivo and in vitro. Aging (Albany NY). 2016;8:3552. 
[50] Mostafa DG, Khaleel EF, Badi RM, Abdel-Aleem GA, Abdeen HM. Rutin hydrate inhibits apoptosis in the brains of cadmium chloride-treated rats via preserving the mitochondrial integrity and inhibiting endoplasmic reticulum stress. Neurological research. 2019;41:594-608.

[51] Celik H, Kucukler S, Ozdemir S, Comakli S, Gur C, Kandemir FM, et al. Lycopene protects against central and peripheral neuropathy by inhibiting oxaliplatin-induced ATF-6 pathway, apoptosis, inflammation and oxidative stress in brains and sciatic tissues of rats. Neurotoxicology. 2020;80:29-40.

[52] Tabeshpour J, Mehri S, Abnous K, Hosseinzadeh H. Role of oxidative stress, MAPKinase and apoptosis pathways in the protective effects of thymoquinone against acrylamide-induced central nervous system toxicity in rat. Neurochemical research. 2020;45:254-67.

[53] Thangarajan S, Vedagiri A, Somasundaram S, Sakthimanogaran R, Murugesan M. Neuroprotective effect of morin on lead acetate-induced apoptosis by preventing cytochrome c translocation via regulation of $\mathrm{Bax} / \mathrm{Bcl}-2$ ratio. Neurotoxicology and teratology. 2018;66:35-45.

[54] Dhanasekaran DN, Reddy EP. JNK signaling in apoptosis. Oncogene. 2008;27:6245-51.

[55] Cagnol S, Chambard JC. ERK and cell death: mechanisms of ERK-induced cell death-apoptosis, autophagy and senescence. The FEBS journal. 2010;277:2-21.

[56] El-Dessouki AM, El Fattah MA, Awad AS, Zaki HF. Zafirlukast and vincamine ameliorate tamoxifen-induced oxidative stress and inflammation: Role of the JNK/ERK pathway. Life sciences. 2018;202:78-88.

[57] Suzuki M, Bandoski C, Bartlett JD. Fluoride induces oxidative damage and SIRT1/autophagy through ROSmediated JNK signaling. Free Radical Biology and Medicine. 2015;89:369-78.

[58] Wang J, Zhu H, Wang K, Yang Z, Liu Z. Protective effect of quercetin on rat testes against cadmium toxicity by alleviating oxidative stress and autophagy. Environmental Science and Pollution Research. 2020;27:25278-86.

[59] Rahaman MS, Banik S, Akter M, Rahman MM, Sikder MT, Hosokawa T, et al. Curcumin alleviates arsenicinduced toxicity in PC12 cells via modulating autophagy/apoptosis. Ecotoxicology and Environmental Safety. 2020;200:110756.

\section{Figures}



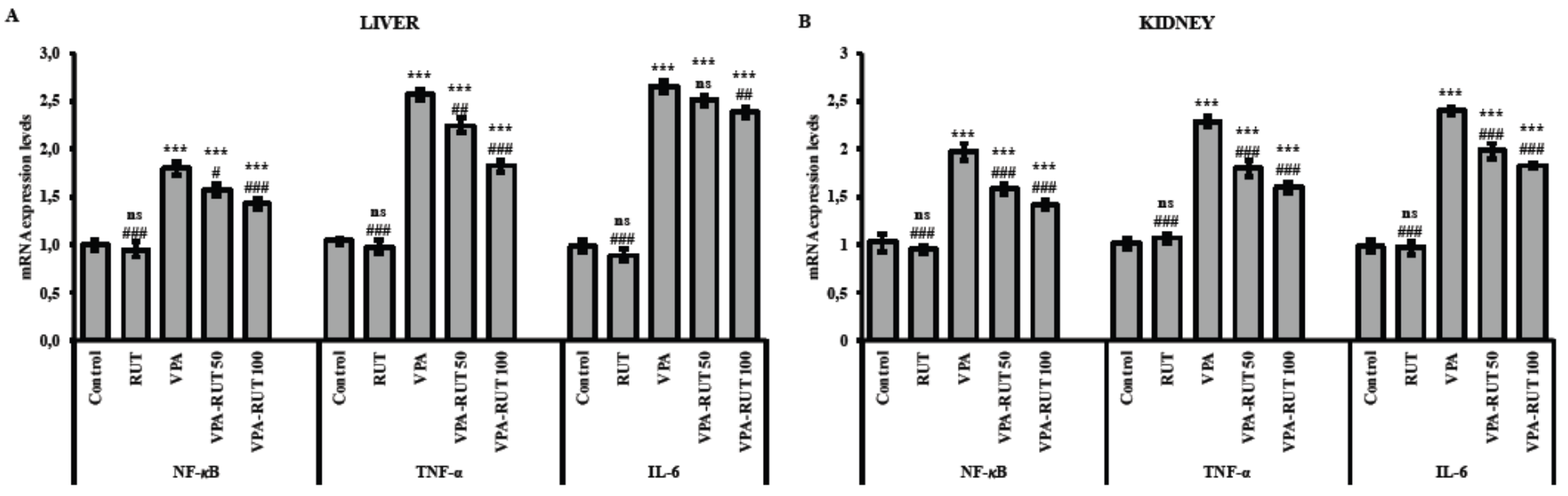

Figure 1

NF-kB, TNF-a and IL-6 mRNA transcript levels in liver and kidney tissues of rats after VLP and/or RUT treatments. A: Liver, B: Kidney.
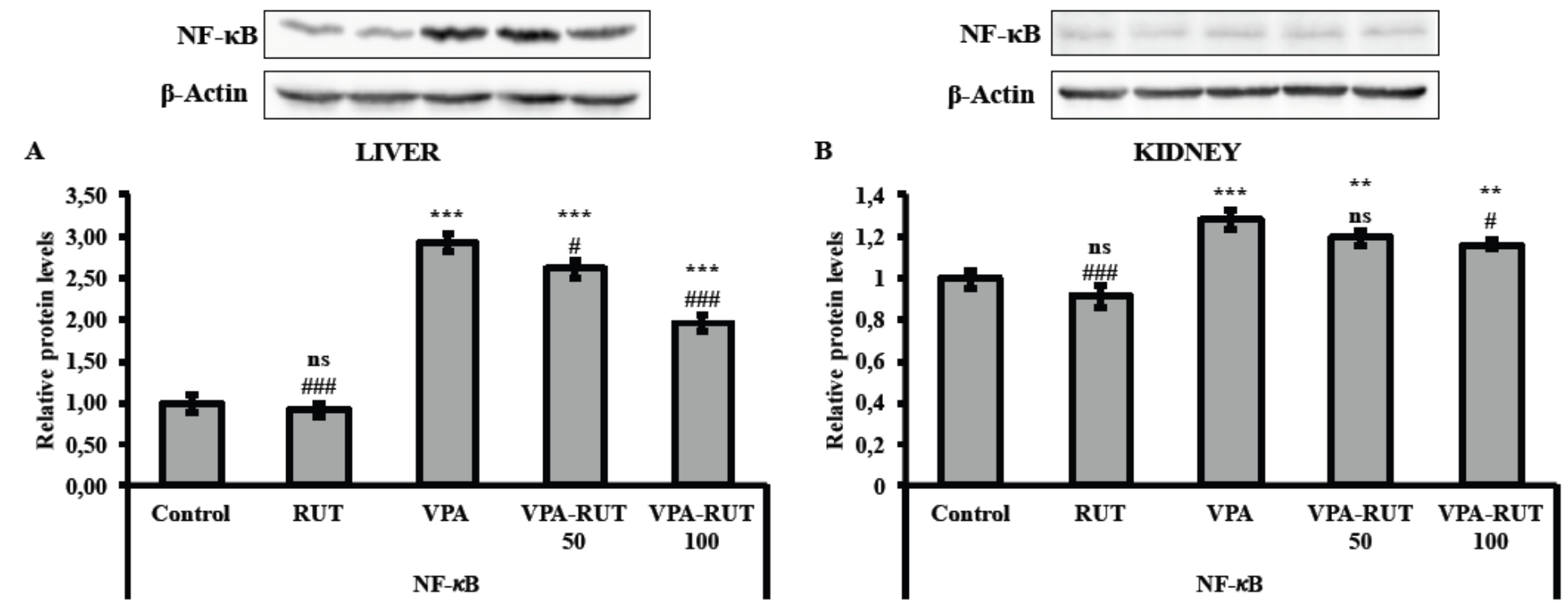

Figure 2

NF-kB protein levels in liver and kidney tissues of rats after VLP and/or RUT treatments.A: Liver, B: Kidney. 

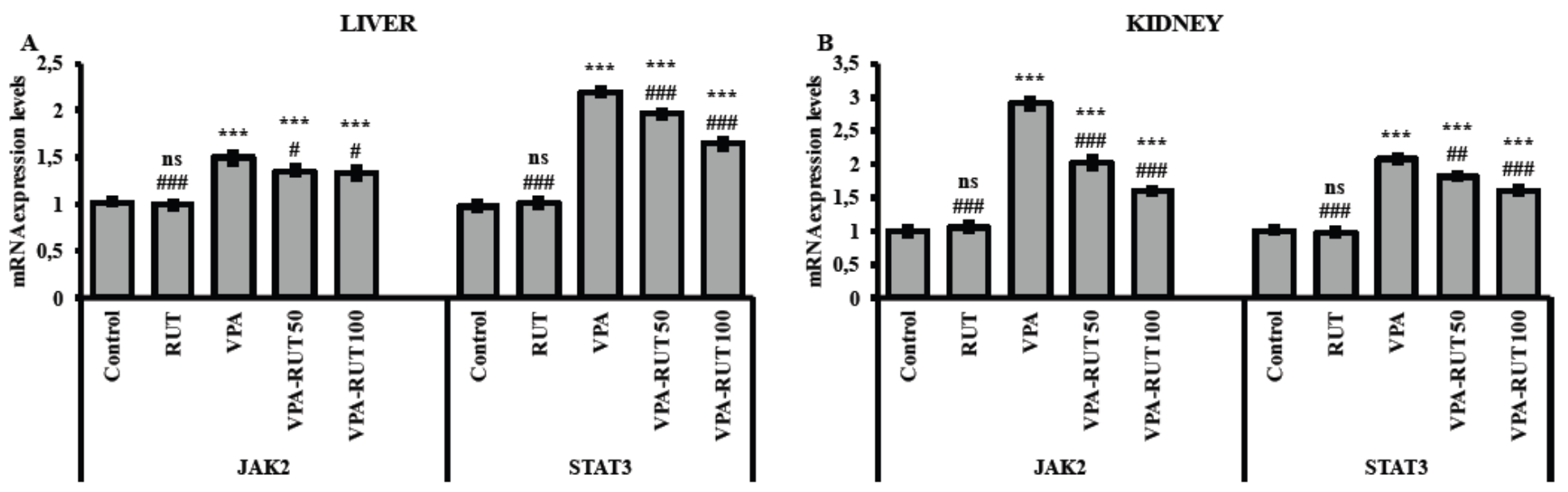

Figure 3

JAK2 and STAT3 mRNA transcript levels in liver and kidney tissues of rats after VLP and/or RUT treatments.A: Liver, B: Kidney.

A

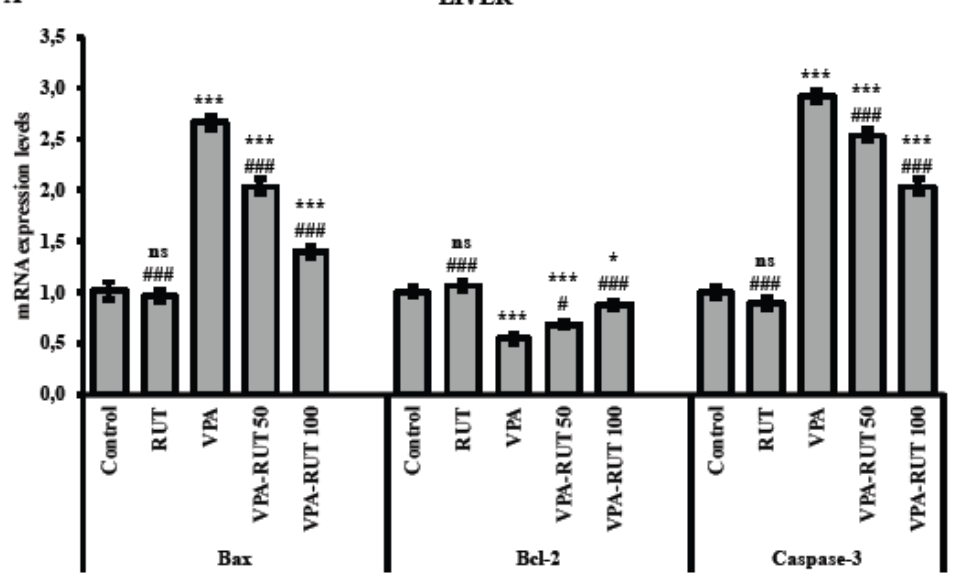

B

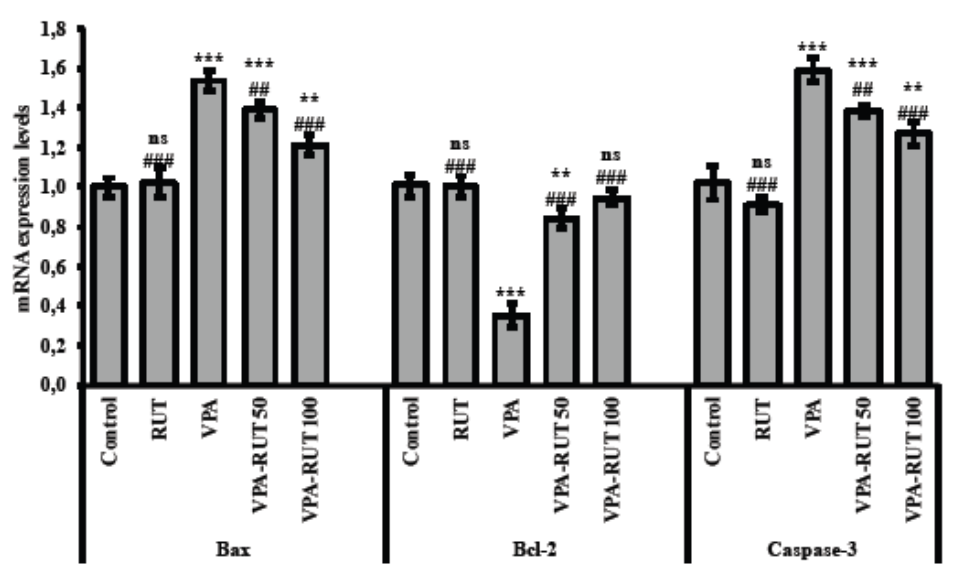

Figure 4

Bax, Bcl-2 and caspase-3 mRNA transcript levels in liver and kidney tissues of rats after VLP and/or RUT treatments.A: Liver, B: Kidney. 

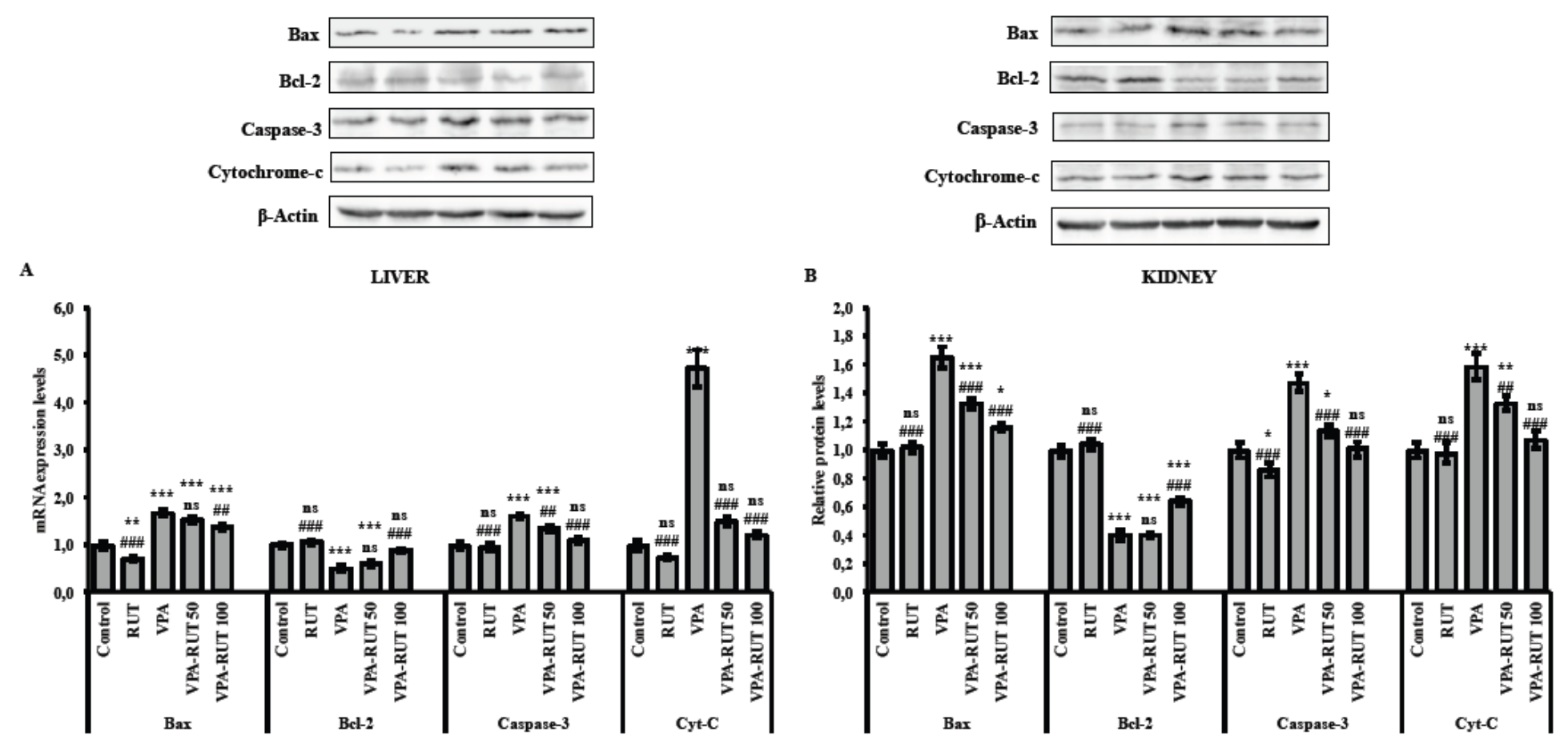

Figure 5

Bax, Bcl-2, caspase-3 and cytochrome $\mathrm{C}$ protein levels in liver and kidney tissues of rats after VLP and/or RUT treatments.A: Liver, B: Kidney.

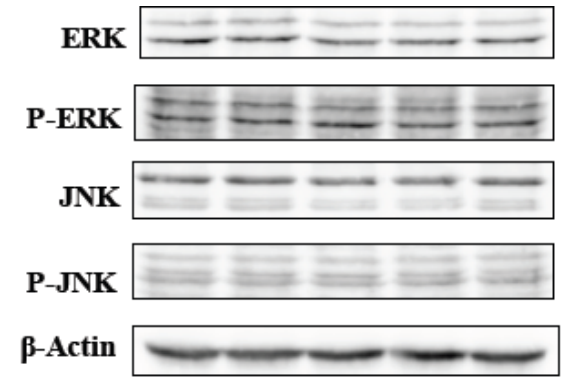

$\mathbf{A}$

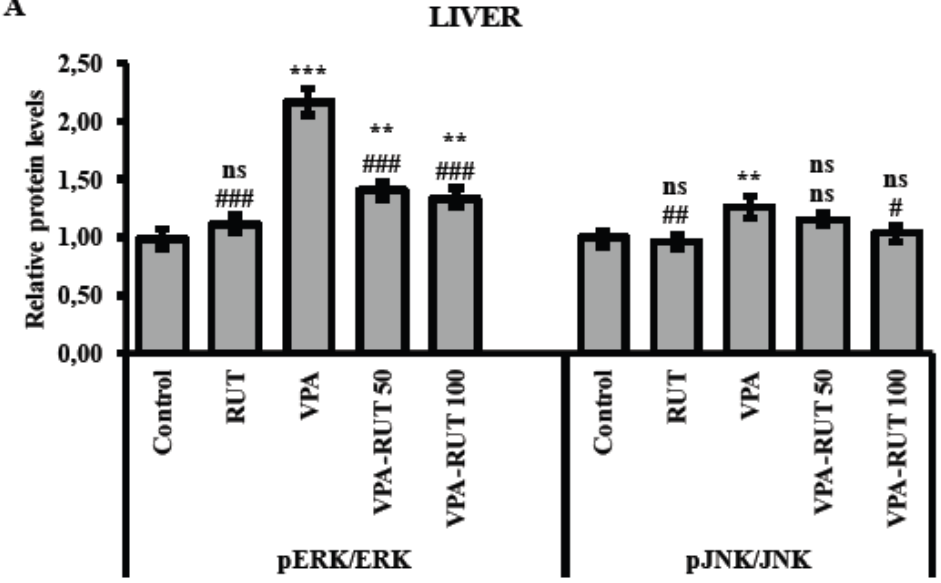

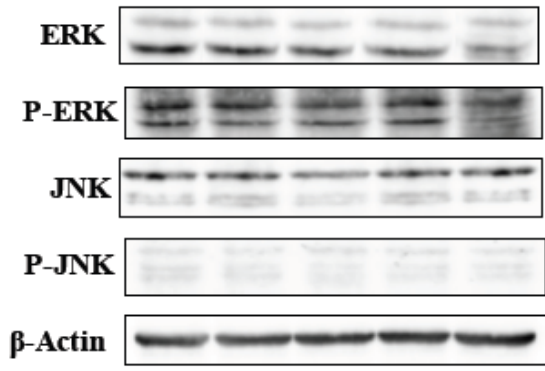

B

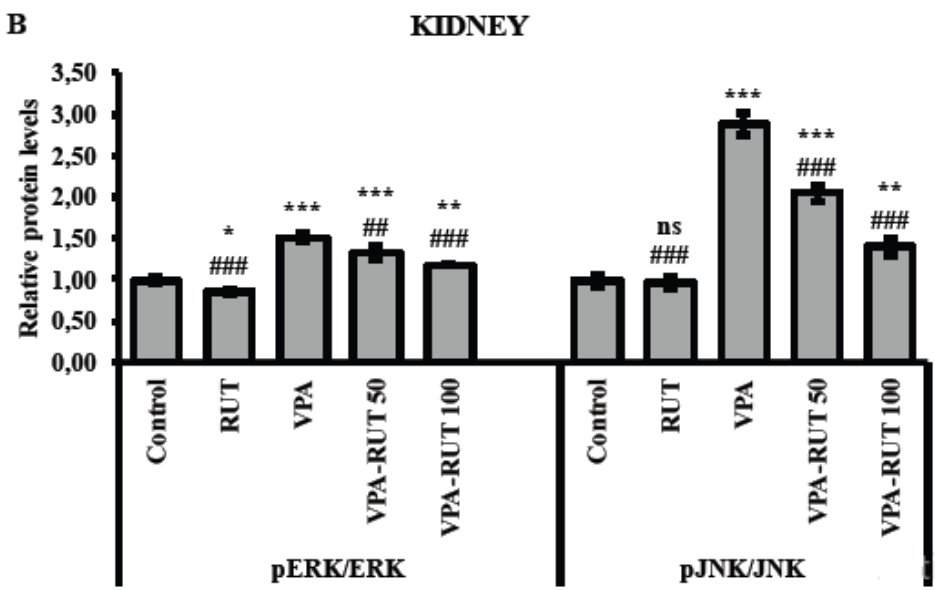

Figure 6

Protein levels of $p E R K / E R K$ and $p J N K / J N K$ in liver and kidney tissues of rats after VLP and/or RUT treatments.A: Liver, B: Kidney. 

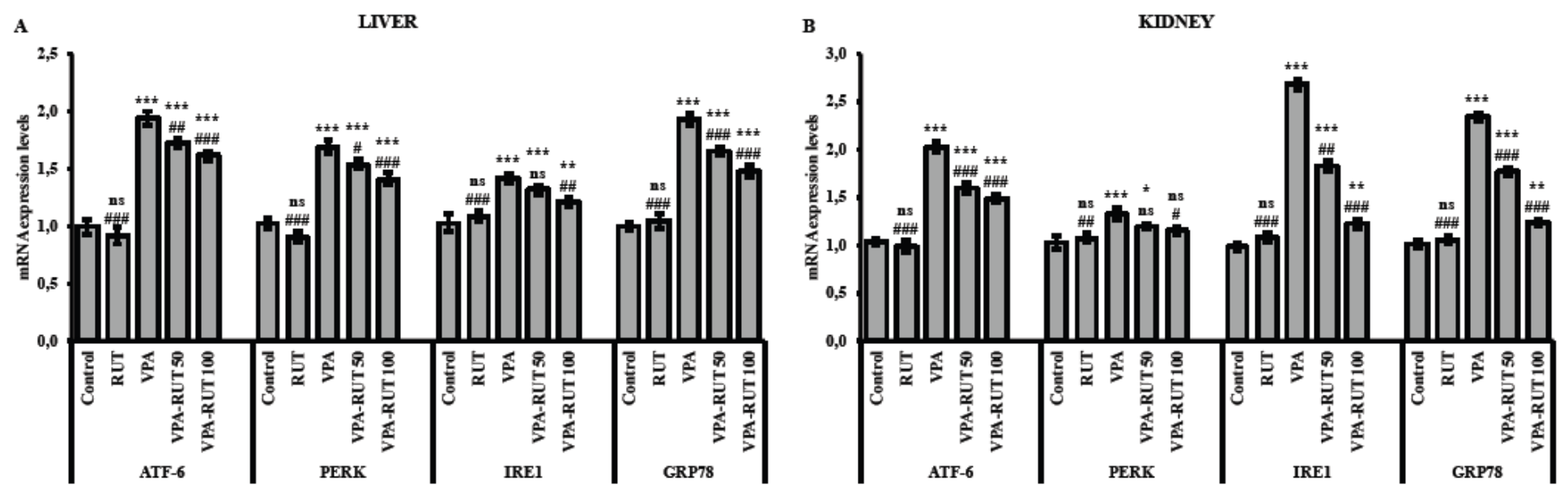

Figure 7

ATF-6, PERK, IRE1 and GRP-78 mRNA transcript levels in liver and kidney tissues of rats after VLP and/or RUT treatments.A: Liver, B: Kidney.

Beclin-1

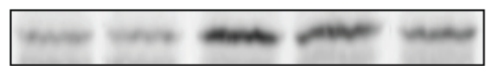

p-Actin

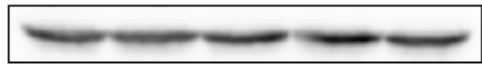

$\mathbf{A}$

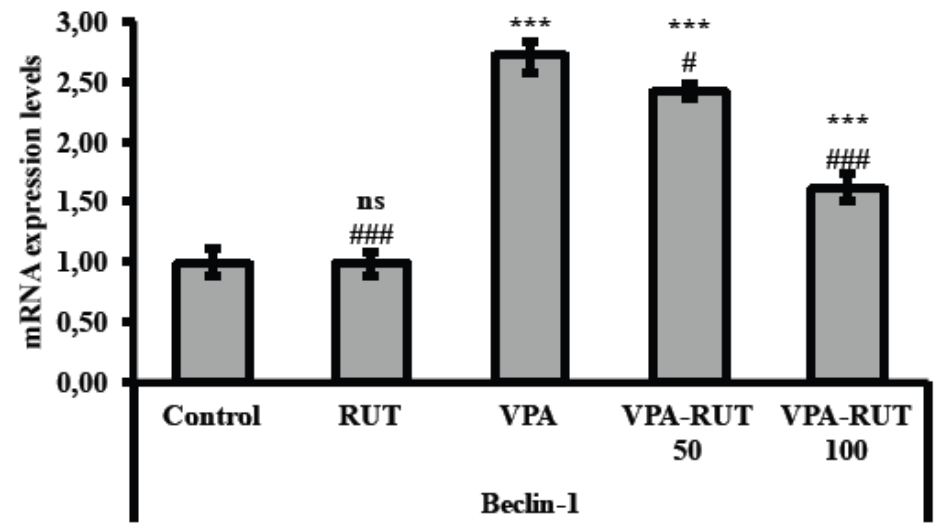

Beclin-1

B-Actin

B

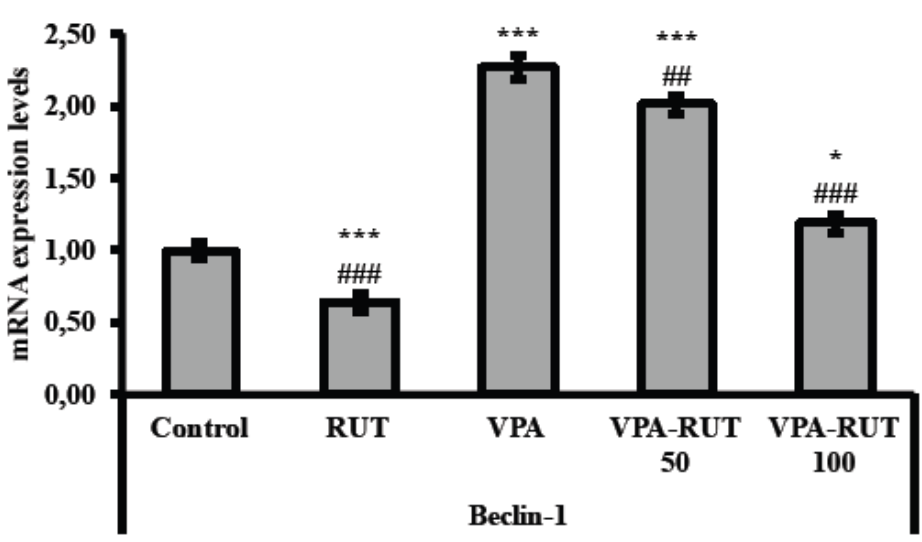

Figure 8

Beclin-1 protein levels in liver and kidney tissues of rats after VLP and/or RUT treatments. A: Liver, B: Kidney.

Figure 9

LC3A and LC3B mRNA transcript levels in liver and kidney tissues of rats after VLP and/or RUT treatments.A: Liver, B: Kidney. 